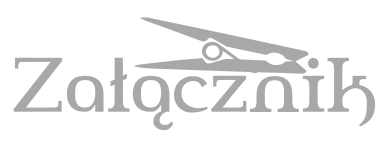

\title{
FAUST/INA. IN RADIANCE BY ARTUR PAŁYGA
}

\author{
JACEK KOPCIŃSKI
}

The Institute of Literary Research, Polish Academy of Sciences jacek.kopcinski@ibl.waw.pl

The publication of new Polish dramas in „Dialog” is sometimes accompanied by an interview with their authors; after the last unusual words of the heroine of the monodrama In Radiance (W płomieniach): 'I stand here, all in radiance / And I turn into the sun' (Pałyga 2016: 72), the interview with Artur Pałyga entitled How to Become Skłodowska (Jak zostać Skłodowska?) was published. I was intrigued by this title. Could schoolgirls from the state grammar school in Włocławek write also today: 'Many of us would like to follow you, but we do not have enough genius and patience that fills you to such a great extent' (Korespondencja... 1994: 224-225), like they did 93 years ago? This cannot be ruled out. After all, whom could contemporary girls admire and with whom could they identify if they would like to become world-famous scientists and win a Nobel Prize? The schoolgirls from Włocławek chose Skłodowska as a role model and the patron of their class, about which they wrote to her in a letter dated June $14^{\text {th }} 1924$ : 'We have hung your portrait drawn by one of us in our school and every day, looking at it, we think about your silent, selfless and committed work. We are really at a loss for words and some strange feelings overtake us' (ibid.: 245). Skłodowska must have felt uncomfortable when reading this confession and, as she basically did not like school as an institution, replied briefly: 'I received your letter only after holidays, but I want to send you at least these late words of thanks for your kind words and wish you good luck at work' (ibid.: 249). It was not a cordial response, but it certainly delighted the schoolgirls. After all, the ideal from the portrait did speak to them!

So, can Pałyga's picture of Skłodowska, who also says in the final part of the work: 'I'd like to howl like a wild animal / But I can't, 'cause I'm already ash' (Pałyga 2016: 72), arouse the imagination of today's schoolgirls? It certainly can, since, according to Monika Żółkoś (2016: 48), who consistently calls the Noble Prize winner a 'scientist' in accordance with new trends, 
the monodrama 'draws the portrait of a woman who is radical in her pursuits, uncompromising, fully committed to work'. Pałyga does not say the same about her, although he stresses that he was strongly moved by Skłodowska's letter to the Nobel Prize Academy, in which she replied with 'dignity', 'rage' and 'pride' to sexist charges made against her because of an affair with a married man, who was also younger than her. Nonetheless, In Radiance is not a literary recipe for a learned feminist with character or a theatrical script of her rebellion. Indeed, the subjective narration included in this work really 'releases the voice from the inside of female experience' (Żółkoś 2016: 48), but at the same time it transforms this voice and experience in a surprising manner. The intriguing title of the interview with Pałyga refers mainly to his own creative attitude, which admittedly has something in common with grammar school pupils...

\section{SÉANCE}

Below there is a fragment of the aforementioned interview:

When I write, I try to become characters that I write as far as possible. I cannot write in any other way. And I turned into Maria at nights, from midnight till four or five in the morning, or sometimes at daytime, from twelve till five in the afternoon. But also I did not want to make a play about myself involuntarily - it was supposed to be a reliable biographical monodrama. I hit upon the idea of the letters she never sent to herself, but still it was not the proper spark. Finally I sat down and started to strike matches and hold them until my fingers got burnt. And I thought that she did the same. And that we feel the same pain in our fingers. And that is it. It has come. I guess that Skłodowska would have ridiculed me. Although she attended a few séances with Pierre, she quickly realized that it was a misconception. I would not exaggerate, too - her spirit did not haunt me (this rather happened when, writing about Morrison, I made a request to him: 'Talk to me!'), I simply tried to perform an exercise and imagine what I would feel and think as young Marysia or old sick Maria. I also had little sleep during exercises (laughs) (Jak zostać Skłodowska... 2016: 78) .

An interesting confession that speaks much about the sensitivity of this author, his techniques and approach to drama. Although Pałyga is ironic about his artistic 'exercises' in imagination, he does not hide them and openly says about his desire 'to become Maria', which means an attempt 
to identify with the heroine to the fullest, almost intimate extent. These exercises really resemble a séance in which the writer acts as a medium for a dramatic character: he would like to summon her from non-existence, feel her within himself, speak her voice and maybe also experience her existence in some aspect of special importance to him. Obviously in imagination, which requires not only spiritual, but also - as we can see - sensual stimulation. A person like Skłodowska might have stimulated Pałyga’s interest in spiritualism, which the scientist treated very seriously for some time. The writer seems to underestimate this motif of her unusual life in the interview, even though he does otherwise in the monodrama. However, before going on to read In Radiance, let us listen to Maria's biographer Barbara Goldsmith (2005:109-110):

The Curies along with their circle of scientist friends - including Crookes; Jean Perrin and his wife, Henriette; Georges Gouy, and Paul Langevin - explored spiritualism as did Pierre's brother Jacques, who was a fervent believer. Pierre and Marie attended many séances, most notably with the Italian medium Eusapia Paladino. They regarded these séances as 'scientific experiments' and took detailed notes. The historian Anna Hurwic wrote that the Curies 'thought it possible to discover in spiritualism the source of an unknown energy that would reveal the secret of radioactivity.' (...) A few days before his death Pierre had written of his last Paladino séance, 'There is here in my opinion, a whole domain of entirely new facts and physical states in space of which we have no conception'.

Goldsmith believes that, after Pierre’s death, Skłodowska 'seem[ed] to speak to her late husband like a spiritualist in her diary' (ibid.: 131), and the convention of a conversation with a dead person is exceeded in favor of direct contact between both persons in this document. Skłodowska speaks to her late husband and listens to his answers, although only despair after the loss of the beloved person may make her behave like a medium. However, spiritualism really seemed to attract her, particularly because its creator Hippolyte Rivail, himself engaged in mathematics, physics, chemistry, astronomy, physiology and anatomy, treated it as a science and addressed his theories to scholars, writing: 
As the invention of the microscope has revealed to us the world of the infinitely little, the existence of which was unsuspected by us, and as the telescope has revealed to us the myriads of worlds the existence of which we suspected just as little, so the spirit-communications of the present day are revealing to us the existence of an invisible world that surrounds us on all sides, that is incessantly in contact with us, and that takes part, unknown to us, in everything we do. Yet a short time, and the existence of that world, which is awaiting every one of us, will be as incontestable as is that of the microscopic world, and of the infinity of globes in space. Is it nothing to have made known that new world, to have initiated us into the mysteries of the life beyond the grave? (Kardec 1996: 421).

In The Spirit Book, Rivail's first and most important work (published under the pen name Allan Kardec), the author's questions were italicized and spirits' answers were put in inverted commas; the remaining fragments are the author's comments:

Have souls a determinate, circumscribed, and unvarying form?

'Not for eyes such as yours; but, for us, they have a form though one only to be vaguely imagined by you as a flame a gleam, or an ethereal spark'. Is this flame or spark of any color?

'If you could see it, it would appear to you to vary from a dull grey to the brilliancy of the ruby, according to the degree of the spirit's purity'. Genie are usually represented with a flame or a star above their foreheads-a sort of allegorical allusion to the essential nature of spirits. The flame or star is placed upon the head because the head is the seat of intelligence.

Do spirits employ any time in transporting themselves through space?

'Yes; but their motion is as rapid as that of thought'.

Is not thought the movement of the soul itself, a transportation of the soul itself to the place or the object thought of by it?

'Wherever the thought is, there the soul is, since it is the soul that thinks. Thought is an attribute' (ibid.: 90-91).

Skłodowska must have known these dialogues, which were popular in the circle of French intellectuals, and the image of spirits with a flame on the forehead (they were imagined like this mainly by occultists like Nostradamus, whose books were studied by Faust) may have been particularly appealing to her. In one of her youth letters, she wrote about her burning head and wittily compared herself to a match. Pałyga even states that she 
liked playing with fire (probably because of cold weather) as a tutor in Szczuki ('where I traveled three hours by train and four hours by sledge from Warsaw' [Korespondencja... 1994: XI]), but we do not know anything certain about this. We know, however, that Pałyga burnt his fingers with a living flame in order to recall Maria - as if he were taming the fire element in order to release a spirit from it in a mysterious ritual... And he read her correspondence very carefully.

\section{ELEMENTAL POETRY IN ACTION}

The subtitle of Pałyga's monodrama is: Completely Unknown Letters of Maria Skłodowska-Curie, which almost exactly corresponds to the composition of the work, encompassing also The Prologue - a paraphrase of the first sentences of Maria's famous lecture delivered after her assumption of the chair of the late Pierre Curie, and The Great Improvisation of Maria Skłodowska-Curie in two parts, which is a perverse and unique allusion to Konrad's improvisation from the third part of Forefathers' Eve (Dziady). The remaining parts of the work bearing titles are in the form of letters addressed by Skłodowska to herself; however, her words in them are also directed to Pierre, their two daughters and unborn child, as if she wanted to recall not only herself, but also four of them and to explain her life to them. Of course, the primary addressees of this correspondence are readers of the monodrama, and I admit that when I read Maria's 'completely unknown' letters, I felt it much more strongly than after reading the 'known' letters that had really been written by her and had been collected and made available to a broader public many years later. Maybe because only fragments of them were printed? What is hidden in those dotted spaces in letters to Maria's father, sister, husband, daughters, friend and lover? In order to check this, I would have to renounce intermediaries - editors - and find original versions. Take the sheets filled with words into my hand and read them in the hope that they will speak to me in the scientist's real voice in an unedited and uncensored version. I do not do it, but I read Pałyga's text many times. It is interesting that publishers are a problem to me, while I do accept another intermediary - the writer. I do not trust the publishers, yet I do trust the writer, even though he offers a literary apocrypha to me. Maybe this is because he behaves like a medium himself... 
In Radiance has nothing to do with an occasional compilation of Skłodowska's letters or with their critical 'rewriting'. It is rather the writer's personal reply to the scientist's thoughts that absorbed his attention most strongly and the amplification of the motifs present in her correspondence that appealed to his imagination most vividly. Pałyga reads Maria's letters, literally interprets her words, though not in order to reveal any faults, and cunningly alters the meaning of quoted phrases: 'Human curiosity is uncontrollable / It will find and disembowel everything, and it will add what it will not find' (Pałyga 2016: 56-57) says Maria. Pałyga is curious about it, but not in such a way. He adds certain things, though not those that are not even mentioned by the scientist. He listens to her voice to hear it better, not to drown it out; however, imitating Skłodowska's slightly old-fashioned style, he often departs from it, breaks the phrase, modernizes the language and applies an entirely new rule to it. His heroine often uses 'nice sentences', like in real letters from the end of the $19^{\text {th }}$ century, trying to be precise, logical, comprehensible and unambiguous. This clear style of speech expressed in writing is her defense against 'tentacles' of human curiosity that 'force' their way into the gaps of someone else's life. But these 'nice sentences' frequently change into a stream of living speech that sounds like a dramatic poem:

I am not writing this letter.

I am speaking it - after all, nothing is lost.

Words radiate (ibid. 55).

They 'radiate' with meanings and energy of the speaker. Maria's language is poetic because it submits the reality to surprising transformations with the force of metaphors hidden in it and triggers sudden associations of thoughts, feelings and impressions with the power of juxtaposed words like in an avant-garde poem. It is interesting to notice that the ordinary Polish word 'radość' (joy) contains exceptional radioactive radium ('rad') and a sharp prickly fishbone that we can choke with ('ość'). However, Skłodowska's monologue is also dramatic: it pulsates with the presence of a speaking girl and then woman, expresses her reactions, her exultation, fatigue and pain and reflects the dynamics of thoughts and the heat of desires; in short, it imitates an exceptional action. I do not know any other text in which a scientific experiment would undergo a poetic and dramatic transformation! Obviously, numbers, geometrical shapes, chemical 
compounds and physical phenomena have inspired poets, and when Maria 'improvises' the separation of polonium and then radium, futuristic poems by Tytus Czyżewski - for example, his Poem of Figures (Poemat liczb) from 1920 - come to mind. However, futurism - a movement inspired both by science and by spiritualism or magnetism - is not the only literary affinity that can be indicated. In Maria's monologue, we can also hear the voice of the main protagonist of Jarosław Marek Rymkiewicz's drama An Anatomy Lesson by Professor Tulp: According to Rembrandt (Lekcja anatomii profesora Tulpa: według Rembrandta) from 1964, in which the active poetic description refers to a post-mortem examination. Maria's 'elemental poetry' in her dramatic action sounds like this:

Hydrochloric acid for pitchblende.

An acid solution.

Hydrogen sulphide is added.

Only uranium and thorium are left in the solution.

What has separated from the solution, note, what has separated from the solution is more active than uranium and thorium as a whole.

What is it?

What is it?

If uranium requires the death of a star, what does it require here?

What do we have in our hands?

I examine.

It is a mixture of metal sulphides: lead, copper, bismuth, arsenic and antimony.

That is all we know.

And the unknown?

(...)

So, it is pitchblende!

We treat it with chlorine, and we come up with chlorides

$\mathrm{U}, \mathrm{Th}, \mathrm{Pb}, \mathrm{Cu}, \mathrm{As}, \mathrm{Sb}, \mathrm{Bi}$ and $\mathrm{X}$ !

There is sediment.

Sulphides

$\mathrm{Pb}, \mathrm{Cu}, \mathrm{As}, \mathrm{SB}, \mathrm{Bi}$ and $\mathrm{X}$ !

And (NH4)2S on it.

Three are left.

$\mathrm{Pb}, \mathrm{Cu}, \mathrm{Bi}$.

And the fourth one, like the fourth musketeer - X. 
And NH3 on it.

And there are hydroxides $\mathrm{PB}, \mathrm{Bi}$ and $\mathrm{X}$ !

And $\mathrm{H} 2 \mathrm{~S}$ on it.

And there is still $\mathrm{Pb}, \mathrm{Bi}, \mathrm{X}$.

So nothing changes.

Then there is sublimation.

700 Celsius degrees.

And this is it!

On one side, PbS1, BiS3 go away to heaven, and we get to the middle of hell. $\mathrm{X}$ !

Let's call it polonium! (ibid.: 61)

Speaking aloud, Maria not only explores and creates worlds, but she also becomes more real. She will tell us about it straight out, although Pałyga formulates her thought in a manner suggesting that it is not only a matter of direct meeting with the heroine, but also with reality: 'I am speaking aloud in order to restore realness', states Maria and she will fight for this realness, also when she loses the thread... So she wants to 'restore realness' and tells us about this, and she immediately adds mysteriously: 'To get out of something like becoming something' (ibid.: 55). Maria is thinking aloud about becoming someone else; like substances being heated by her, she is subject to constant change, which leads to the separation of what is the most important in her. Speaking, she 'gets out of something' and becomes 'something' anew, as if the internal transformation of the human being required not only his/her will and reflection, but also his/her action going hand in hand with words. A written letter will be only a dead memory of this mysterious process, whereas a letter spoken here and now, in real time, addressed to someone, even to herself, a letter changed into an act of living and direct communication that is extraordinarily based on the word being subject to intense thought and the surprising work of imagination, a letter-action is that process itself. It is a powerful carrier of an experience changing personality that can be triggered - and experienced! - not only by an actress performing Maria's monologue, but also by its reader. Quoted already in The Prologue, the main definition of radioactivity - 'Radioactivity is the transformation of one element into another through the emission of radiation' perfectly expresses the principle and aim of this monodrama. 


\section{IN THE THICKENING DARKNESS}

We already know that it was created by an ignitable match... In her letter to a friend dated March $13^{\text {th }} 1889$, twenty two-year-old Maria wrote: 'My head burns so much, it is so full of projects that I can't get along. You see, while Your Mania is alive, she will be a match of matches!' (Korespondencja... 1994: 19). Like most girls from her generation, young Maria devoured poetry, translated foreign poems and wrote her own; thus, witty playing with phrasemes was nothing special to her. Therefore, even in a 'nicely' written letter she does not write about her 'feverish head', but about her head being 'on fire'; she will immediately associate this image with a burning match (which also has a head) and... will become it immediately. Obviously, she will not become an ordinary match, because the metaphor (which initiates the metamorphosis!) assumes thinking and Maria wants to be a scientist, so she will be a 'match of matches', a big one, the biggest one, like a Biblical song... Nevertheless, she will be a match - like the one for burning a candle or a gas lamp - rather than a torch or firebrand that has ignited the imagination of many poets. Pałyga noticed that difference and caught hold of this match, i.e., he followed Maria's youthful, poetically 'un-overscaled' imagination, yet, he also let his own fantasy work; thus, around this motif, a dramatic situation of key importance for the entire monologue arose in his work: 'I'm here, in the thickening darkness / There is a table, a card, and an unlit lamp in front of me. // In front of the lamp there is a match' (Pałyga 2016: 72), says Maria to herself from the future in the first monologue entitled Entrapment.

Each further letter is spoken by an increasingly more mature woman; this one is spoken by an 18-year-old. She is much younger than historical Maria from the letter to Przyborowska, and she is celebrating her birthday. A lonely November evening is an exceptional time for her - a time of transition, change and also trial. The girl has attained maturity and, at the beginning of her adulthood, experiences this kind of existential shock where the sense of passing plays the most important role. 'Big Mania', 'Mania in the maturity of her fruitful life' realizes 'the minuteness of our life in the infinity of the universe' and she thinks that she is already leaning towards non-existence, she is beginning to disappear and 'fade into this darkness' (ibid.: 51). An incredible, mysterious moment! Maria feels lonely, but also distinct; she did not go to the party although she had been invited. She did not want to waste her short life on insignificant matter; this is made easier 
by her unattractive appearance she even tries to be proud of: 'I'm ugly, and I consider it to be a gift, the biggest gift' (ibid.: 52).

Maria's loneliness, her detachment from people is intensified by the absence of God, who disappeared from her life after her sister's death, which was soon followed by the passing of her mother. Hurt by this double loss, the hitherto religious girl lost faith in God's goodness: 'I've prayed for so many nights, my faith was unshaken and solid as a rock, I believed in: ask and you shall receive. // And both of them died' (ibid.: 62). And when she became a scientist, she completely excluded God from her reflections on life and death. But that was then; now, recalling her adolescent tragedy, she says: 'what has remained, is the void that needs filling in' and she fills it with herself, because she decides to write letters to herself. This surprising idea perfectly reflects the most important traits of Maria's personality: concentrated, introvert and proud, and therefore closed to others, but also looking for a more mature confidant to whom she could confide the most 'shameful' and 'intimate' contents. Maria's monologue was intended by Pałyga to be a kind of confession that Konrad calls the 'discovery of the soul' in Dziady ${ }^{1}$. Maria 'hates Romanticism', and yet her letters are written exactly in this fashion, even though the two fragments of the monodrama that Pałyga called The Great Improvisation of Maria Skłodowska-Curie (Wielka Improwizacja Marii Skłodowskiej-Curie), are devoted to an entirely different discovery - not of the soul, but of polonium and radium. However, in the case of the heroine, it is actually the same... Konrad addresses God in a friendly manner in his confession, but ultimately he reacts with a blasphemy (which is not spoken!) to His silence. Maria does not believe in God, but she longs for the presence of someone similar to Him: 'And I want, I need so much to feel someone's presence - feel that someone sees me, knows about me, understands me' (Pałyga 2016: 51).

If Maria's monologue were spoken by an actress from the stage in our presence, the empathy that we would feel towards this girl could fulfill her desire. But Maria does not speak to an audience - she speaks to herself and chooses herself as this other empathic, conscious and understanding person to whom she can open her soul. Like Henryk in The Marriage (Ślub), Maria

1 'I am uncovering my soul to You like a friend' (Mickiewicz 1974: 200). 
speaks about the void that we would like to call metaphysical and which is signified by darkness both in Gombrowicz's play and in Pałyga's work: 'I'm here, in the thickening darkness,' says the girl, experiencing the loneliness of a modern intellectual on the threshold of her adulthood, which pushes her to create a lookalike character. Writing to herself, Maria pretends to establish her second 'self', but she does that out of her genuine internal need in order to speak herself towards that 'self', or - more precisely - to build herself in accordance with her desire. By 'creating' Władzio (which was an inadvertent act - Władzio emerges from the protagonist's dream in The Marriage), Henryk established someone 'below' himself, someone over whom he could 'rule', force him to commit suicide and become a(n involuntary?) tyrant. Maria has different intentions - she dreams of herself as a more conscious, wiser, greater, even immortal person! Her attempt is not yet undermined with the sense of disaster and internal breakdown that fills the souls of so many literary figures with a nihilistic view and a heart filled with desperation in the middle of the $20^{\text {th }}$ century. Maria still represents the intellectual group that writes the word 'positivism' rather than 'negation' on its highly raised standards, combining the entire (religious, philosophical, poetic) idealism of the $19^{\text {th }}$ century with the realism of laboratory experiments and transforming it into a lofty scientific world view: 'So let's work', calls Maria. 'Let's work as long as the light of the day and the small light of the night shines for us'.

Pałyga perfectly captured this dimension of Skłodowska’s spiritual construction - he emphasized it, but also analyzed it from a deeper poetic perspective. First of all, he filled Maria's monologues with alchemical symbols, recognizing the esoteric Faustian myth in her unbending knowledge-seeking attitude that fascinated schoolgirls from Włocławek and the entire world so much. Skłodowska’s actions - her endless attempts to separate various substances by heating them to a higher and higher temperature - were put by Pałyga into the framework of an occult ritual whose artistic representation is the monodrama itself. In Pałyga's work, Maria exerts her influence not only on matter, but also on herself; her scientific practices affect directly her physical and mental condition and not only broaden her knowledge, but also change her views and shape her personality. In Radiance makes us realize that, contrary to positivistic assumptions, research work develops the scientist and changes his/her spiritual structure, and this internal 
transmutation process is more difficult to follow, define or measure than the transformation of bodies. 'We acquire the features of things that we've become fond of, that our life sticks to', says Maria, and she adds: 'I am radium'. With every word, she enters a higher level of her consciousness.

\section{THE BRIGHT RAY OF TRUTH}

So, how does Maria perceive herself? How does she understand herself - now and in the future? What does her monologue reveal? She is (will be) proud and alone, she is (will be) different and she is (will be) determined. She wants to dedicate herself to science in order to tear out from the world the secrets that will make people happier. In the darkness, the metaphysical void, a flame is born and a scientist is born who, like Prometheus, is ready to steal fire from the gods and bring it to people even at the cost of martyrdom. She is irritated by this word, but the experience behind it clearly attracts her. She takes a match in her hand and analyses the ingredients from which it was made (wood and phosphorus), thinking about this strange 'element' that brings so much good and so much evil; then she lights the stick and holds it until it burns out in her fingers, ready to bear an even stronger pain in the future. 'I disappear in pain', she says. 'There is only will'. And sheer will is the thing that would like to become above all elements, the will that is resistant to everything that weakens it. To physical and mental pain and all obstacles, like the fact that she is a woman, that only men are allowed to study in her epoch, that she is a Pole, that knowledge in her country is the domain of Russians, that she is poor and learning is expensive, that she has to live with people who always expect something... And that she is within the body that is subject to fatigue, illness, old age...

How to avoid succumbing to human weaknesses when you are a human? Self-exercise is necessary, so Maria invents her private 'ritual' of fire. But that is not enough. In order to go outside our own limits, we need stronger help, and Maria knows that making it up is not sufficient to hold on. Therefore, on that night, in the complete solitude of her dark room, she not only establishes her second 'self', but also summons someone. This happens in sheer reality: the whole world calms down, the match burns, Maria moves her fingertips closer to the bright flame and then a voice is heard: 
The flame speaks to me.

'Mania', it speaks to me.

Like someone close to me, the closest one, a member of the family, the nearest family.

'Mania', speaks the flame.

'I am', I say.

I am.

And I'm afraid.

And I feel the rising fear, the panic that must be suppressed.

And my fingers already feel hot.

I want.

I can.

I ask.

I demand.

I order.

Let it arise here.

Here in front of me.

Like in front of Faust.

For the world.

For humanity.

Am I ready?

Yes, I'm ready.

For everything?

Yes (ibid.: 54).

Maria knows that when the pain comes and can be endured, the world (along with all those unaware people) goes away and there comes... who? 'Like in front of Faust' - the Spirit of Earth, maybe Mephistopheles himself? It amounts to the same - the entire scene refers to Faust. Pałyga fills it with a multitude of allusions to the first scene of the first part of Goethe's tragedy entitled Night:

The lamp flickers!

Now it dies! Crimson rays dart

Round my head - Horror

Flickers from the vault above,

And grips me tight!

I feel you float around me, 
Spirit, I summon to appear,

speak to me!

$(\ldots)$

He grips the book and speaks the mysterious name of the Spirit. A crimson flame flashes, the Spirit appears in the flame (Goethe 2003).

The first monologue of In Radiance is Maria's night - the night of her 'liberation'. We can see the similarity in words, objects, images, and the very situation of talking to a flame, which is a clear reference to occult practices in Faust ${ }^{2}$. Maria lights a match and ignites the thought that suddenly breaks away from her and speaks to her like an arriving guest. Just like Faust's heart, her heart 'laces up' the fright that she must overcome to release herself and gain enough power 'to flow through Nature's veins, and, in creating, enjoy the life divine' (ibid.). This is the direction in which Pałyga will lead the further parts of the monologue spoken by Maria, for whom the examination of nature will be also the creation of its unknown elements and the establishment of dimensions of which we are unaware. Maria's desire is not caused by some scientific disillusionment following many years of hard research work; she is rather guided by the same poetic cognitive passion that we know from Adam Asnyk's poems weaved into Pałyga's monodrama:: 'Look for the truth of the bright flame! / Look for new undiscovered roads...' recites Maria and then she soberly adds: 'And I'm looking, looking for a flame with my burnt hands, right? / Only with this God...' (Pałyga 2016: 62). Thus, the key moment for the initial Faustian situation is the one when Maria gains control of the pain and fear, and the power of will guiding her releases not only the brave, rebellious and almost desperate thought, but also the second voice that puts the future scientist to the test. No, Mephisto does not appear in Pałyga's monodrama, although Maria will summon his name in adulthood; as Małgorzata Szpakowska (2016: 81) aptly notices, nobody gives the girl any guarantees that 'things will turn out right and her effort will not be in vain'. However, it is the internal decision that counts. Maria is ready for everything and will endure everything, 'even when' - what?

2 Specifically, it refers to the 'smaller pentagram driving the ritual away'. See: Abyss 2007: 42. 


\section{THE FAUSTIAN ARRANGEMENT}

The thought of Maria's 'Faustian arrangement' appears also in her biography by Barbara Goldsmith. The author of Obsessive Genius associated it with the second Nobel Prize, which Skłodowska received for the discovery of polonium and radium, the separation of pure radium and the examination of properties of radioactive elements. The prize popularized the new elements, particularly radium, which was treated as a miraculous antidote to all diseases, particularly cancers, even though these were actually caused by it - Maria died of leukemia as a result of intense radiation with radium. She paid with her health and life for the international fame that brought her the opportunity for further experiments, although it did not make her rich (the discovery was not patented by the scientists); moreover, she exposed many other persons to the risk. In Goldsmith's biography, we come across the recurring motif of the scientific obsession that pushes aside Maria's own good and the good of people close to her to the background of everyday life. Skłodowska literally loses herself in the work that exposes her to a huge danger. According to her calculations, the radium separated from pitchblende was to be 'several hundred times more active than uranium'.

She was mistaken. One tenth of a gram of pure radium chloride would prove to be ten million times more radioactive than pure uranium. Four years later, Pierre Curie said that had it been his choice, he never would have attempted the task of isolating radium. For Marie there was no choice (Goldsmith 2005: 73)

The last sentence of Skłodowska’s biographer sounds very ominous, as if Maria's attempts were not voluntary, but the scholar's determination to separate radium had purely scientific grounds. The theoretical discovery of the new element could satisfy physicians 'working with the properties of rays' (ibid.: 73), who could regard the source of radiation as real on their basis. On the other hand, chemists expected a substance, and Maria was determined to deliver it to them, in spite of the absence of proper conditions. The work that she performed with Pierre Curie's help in her simple laboratory in a shed should have been carried out by a large team of persons equipped with appropriate devices. Another problem was that only Maria with her extraordinary skills could perform necessary measurements during reactions she created. The fatigue resulting from many months of experiments was not 
the only price she paid for milligrams of radium isolated from many tons of clay. Skłodowska also suffered from recurring depressions. Goldsmith suggests that in December 1903 the scientist did not travel to Sweden to receive the Nobel Prize because of the depression that was a consequence of her miscarriage:

The previous summer, although five months pregnant, she had taken a bicycle trip with Pierre, who had emphasized how much he needed her company, oblivious to the danger such a strenuous trip might entail. After three weeks of constant biking, Marie suffered a miscarriage. When she could obsessively throw herself into work, she could keep going, but now the arduous labor was behind her. She was depleted physically and had not yet had time to mourn the loss of her father or her unborn child. The following week she took to her bed, speaking little, eating less, ignoring Irène, rousing herself only to teach her classes at Sèvres (ibid.: 88).

In 1912, she collected her second Nobel Prize personally, but after her return to Stockholm she was hospitalized due to suspected kidney failure. Although she underwent an operation, the reasons of her collapse are not clear. Symptomless tuberculosis was suspected, too:

What was not said was that she had experienced a total nervous breakdown and had fallen into the deepest, darkest depression of her life, more enduring than all the episodes that had come before. Later she told her daughter Eve that this time she wanted to kill herself and indeed some of her letters indicate that she planned to commit suicide (ibid.: 141).

However, these letters are unknown to us. Or maybe the suicidal thoughts of the great scientist were dotted out by publishers of her correspondence? In 1911, Maria experienced not only the miscarriage, but also the tragic death of Pierre Curie, who was run over by a horse-drawn cart (the scientist's head was literally crushed by a wheel) and the mentally devastating affair with the younger Paul Langevin, for which she was stigmatized. Thus, the 'Faustian arrangement' - if we assume this risky interpretation of events experienced by Skłodowska - involves also Maria’s 'forbidden' love and suicide attempt; fortunately, the latter did not materialize. Faust tried to commit suicide, too... 


\section{UN-HUMANISATION}

Thus, the chain of Skłodowska's great scientific successes was accompanied by a chain of her personal misfortunes that evoke associations with the Faustian pact with the devil. In Goldsmith's story, Maria resembles the brilliant composer from Thomas Mann's novel Doctor Faustus. Just like Adrian Leverkühn, she is the discoverer of entirely new worlds in her field and suffers, spending long weeks of her physical and mental collapse in the perpetually darkened bedroom that resembled a grave (ibid.: 141). But this was not the only motif linking her with the protagonist of Mann's novel. The biggest shock for Leverkühn was the death of his little child Nepomuk, for whom the composer and his whole home environment had deep affection and whom they called Echo (which means old times and forgotten childlike faith). The boy prayed for the whole creation in his own way, which surprised and touched Adrian. The composer perceived his sudden death as another, most horrible attack by Mephistopheles, with whom - as it seemed to him he had concluded a pact. By creating the figure of the devil, Mann obviously follows Goethe, in whose work, as Mircea Eliade (1965: 80) writes:

Mephistopheles does not oppose directly God, but Life - His main creation. Instead of motion and Life, it tries to impose stillness, rest and death. Everyone who ceases to change and transform breaks apart and dies. This 'living death' manifests itself in the emptiness of the spirit and is eventually tantamount to condemnation. Whoever allows the roots of Life to die within him, he submits to the Spirit of Negation.

The Satanic dialectic! Mephistopheles stimulates the human cognitive and creative attempt and, at the same time, establishes death as its opposite and necessary condition, which is permanently inscribed in development, progress and all human actions. In Pałyga's monodrama, Maria summons Mephisto at the moment of her epochal discovery (performing the polonium separation process in front of us) and immediately asks:

What has to be sacrificed?

What do you want, Mephisto?

If we sacrifice our own life, this is forgivable.

If we sacrifice ourselves on the altar, this is great, superhuman, admirable. And if not ourselves? 
If someone else?

If you, child? (Pałyga 2016: 66).

Maria seems to be speaking about the child that she miscarried, and this motif makes us think about infanticide Margaret from Faust and Susanna Margareta Brandt - the prototype of this character, who was accused not only of infanticide, but also witchcraft and beheaded in Frankfurt in 1772 (Schöne 1996: 214). First, still being pregnant, she addresses her child as a son, but after the miscarriage she will say: 'Look, daughter!', because she already knows the child's sex. 'You hurt so much, daughter!' she will call at another moment, as if recalling the moment of the approaching delivery, although the pain to which she refers may also be understood a spiritual sense: 'My child was dead when it came out of my body. / My daughter. My little daughter. My child. It was sacrificed.' But Maria does not have ordinary qualms of conscience. In her unusual trance-like hyperconsciousness (and relationship), death constantly blends with birth, creating one reality of constant change, which is not subject to moral evaluation, because it belongs to another non-human order. This rule applies to all animate and inanimate bodies, according to the knowledge proclaimed by former alchemists and contemporary chemists and physicians as well as spiritualists standing between them:

What becomes of the matter and the vital principle of organic beings after their death?

'The inert matter is decomposed, and serves to form other bodies; the vital principle returns to the general mass of the universal fluid'.

On the death of an organic being, the elements of which its body was composed undergo new combinations that form new beings. These, in their turn, draw the principle of life and activity from the universal source they absorb and assimilate it, and restore it again to that source when they cease to exist (Kardec 1996: 50).

The mysterious 'vital principle' is called here a 'fluid', which Rivail (Kardec) will associate with electricity: 'Organic bodies may thus be said to be a sort of electric battery, in which the movement of the fluid produces the phenomena of life, and in which the cessation of that movement produces death' (ibid.: 50). 
As we can see, in the first part of her Great Improvisation... Maria descends: 'into the middle of hell' and separates polonium at an immeasurable temperature, in the fire that destroys everything. In the second part, she makes use of bodily fluids extracted from a dead man's corpse and pours them on the dead rock fallen from Space, thereby separating a new element radium. She destroys living things and brings dead ones to life, and finally she burns to ashes and turns into a ray... However, before Maria fully burns out, she experiences the great Faustian exultation in the second (Witch), third (Tiredness), fourth (Fulfilment) and then fifth and sixth (The Great Improvisation...) part of the monodrama. The spirit of totally unrestrained will transforms the matter of her research and the matter of her life, which mix with each other like clay in a tank and soup in a pot, because Skłodowska, though buried in her work, tries to live up to her responsibilities as a mother: 'To feed the child, mix, heat, warm, cook' (Pałyga 2016: 57).

By means of surprising strings of metaphors, Pałyga equates research and the ordinary everyday reality of a woman in her monologue, which is both a moving and thought-provoking measure. After all, the scientist brings down the material, moral and spiritual aspect of existence to one common denominator, which is called 'radioactivity': 'What kind of light is being emitted by something in this heap?! / What has been born here and for whom?' (ibid.: 59), asks Maria, surprised with having discovered such a powerfully radioactive element. In her mind, polonium is a child, and the child is a compound of elements that radiate in the same way as pitchblende, though to a weaker extent. At the same time, she experienced self-transmutation - in accordance with alchemists' beliefs that inspired depth psychologists in the $20^{\text {th }}$ century (Jung 1990). However, when building Maria's internal biography, Pałyga does not follow the path of Jung's individuation, she does not lead her heroine through stations of successive female archetypes. He is interested in another process, which the scientist tries to name at the very beginning of the monodrama, in the part Witch: 'I feel that I'm undergoing the process of unhumanization, hyperhumanization or subhumanization, I don't know its name' (Pałyga 2016: 55), says Maria, and Pałyga codes in her words the Spirit's line from Goethe's drama ${ }^{3}$ and

3 'I am here! - What wretched terror Grips you, the Superhuman!' (Goethe 2003). 
this key concept (Übermensch) that expressed a higher stage of development of the human being released from moral obligations (Nietzsche 2006). In the $20^{\text {th }}$ century, the same concept became a sign of modern nihilism that led to the methodical extermination of millions of human lives backed up by scientific discoveries and developing technology. Immersed in her scientific trance, Maria does not ask questions about biological, social and moral consequences of her discoveries, although she experiences them herself; she is not concerned about the ethical borders of science, either (see: Galewicz 2013). She still belongs to this epoch of great idealists who naively proclaim the neutrality of research and experiments and whose pockets contain bags of radioactive substances that make their bones crumble (Goldsmith 2005). She represents the epoch of frantic scientific attempts that opened people's eyes to invisible energies, but they destroyed their bodies and took away their souls - i.e., distinctness and uniqueness that disappeared in the cosmos of continuously mutating elements. Observing the glow of radium at night, Maria thinks about the invisible side of existence that has finally been shown to human senses thanks to her work. We are in the very centre of the Faustian myth - the dream of the scientist who wanted to touch the metaphysical rule of the world is coming true.

I assumed, and this was my risk, that something else exists in spite of the reality and expectations of people that I respect and like.

Something that is invisible.

Because our senses are imperfect.

But we have something that strives for perfection it will not attain - and it is perfection.

Namely, science.

Science will reach where the senses cannot reach.

And I do not mean spirits.

Unfortunately, she does not mean people, either - she means humanity at the most... The whole first part of The Great Improvisation of Maria Skłodowska-Curie, this performed description of a chemical experiment that Pałyga likens to the alchemical element transmutation process is actually a record of the Faustian strive for the separation of 'a force from the beginnings of the world, which is penetrating and present.' In the end, her impressively beautiful personification - the author is deeply concerned 
about maintaining this ambivalence - becomes Maria himself. Half-blind, with burnt interiors, fingers like scorched sticks, restless and painful, she becomes the sun and ash at the same time. She radiates and disappears.

\section{SISTER}

In Maria's eleven spoken letters, Pałyga records the lofty world-view of a modern scientist who would say like Skłodowska:

People think that it is a matter of good and evil, of what is moral and what is immoral.

No.

It is a matter of avoiding an error (Pałyga 2016: 54).

He embeds this world-view in the Faustian myth and in alchemical or spiritualistic imagination, perfectly sensing that the rationalism of the Enlightenment is not sufficient for its description. Twenty years earlier, similar intuition was expressed by Jerzy Jarocki when he was preparing the theatrical performance of Goethe's drama in a new translation by Jacek Buras: 'listening to Faust, we feel that there is Something that knows and we still do not know; that the evolution of knowledge has returned to the starting point and that it is not longer the Enlightenment point of view - we find ourselves somewhere else' (Das Streben... 1996: 233)

In order to get nearer to this 'Something', Pałyga takes knowledge back to its magical and mythical beginning, recalling the names of Faust and Mephisto and, eventually, confronting this model of scientific world-view with Christian mysticism and theology. He does this when he composes Maria's monologue in the fashion of Saint Paul's Hymn of Love. If we replace the word 'element' with 'man' in it, and the Gospel allusion suggests such a possibility, the scientist's words will sound to us like a hymn to a new god of science:

Love does not ask whether he is useful, does not expect that he will serve someone or something and does not try to involve him in the harness of some pragmatic forces.

Love is satisfied with his existence (Pałyga 2016: 56).

In view of the ideal of pure cognition, Maria assumes the whole beauty and the whole burden of her discoveries. She does not regret anything and does 
not apologize to anyone for anything. She makes a sacrifice to deified science, and she is ready to burn out and crumble to dust, because such is the superior 'divine' rule of the material world in all of its dimensions. Speaking of science in terms of selfless love, she creates a sort of secular theology that contains also a certain design of humanity. It is based on courage, freedom and the Faustian strive that brings forth human curiosity and the desire for rational cognition and independent explanation of phenomena: 'It was me, your mother, who revealed it. / I turned the invisible into the visible. / It was me,' she will say like the Creator. The collision of two world-views the scientific one and the Christian one - has also a personal and historical dimension in the monodrama, because when Maria says: 'During that oath, I virtually became Faust, Faustina, didn't I? / This was like a pact, like a drop of blood on this devil's paper', she will code an allusion to acompletely different Maria in the feminine form of the name Faust - the one whose true name was Helena Kowalska and who assumed the name Maria Faustina after joining a convent. A surprising association! Kowalska is the spiritual opposite of Skłodowska, even though she seems to be her daughter... Like her, she was not very pretty, shunned people, devoted herself fully to her mission and died of an unrecognized disease. She also wrote letters and, instead of scientific lectures, she kept a diary of her mystical experiences, which were as incredible as experiments carried out by Skłodowska in her shed. Both of them dealt with the 'invisible' for years, which Skłodowska perceived as impersonal energy (associated with spirits by spiritualists) and tried to look, examine, calculate and harness for the benefit of all human bodies suffering and finally crumbling to dust. On the other hand, Kowalska recognised the personal loving God in the 'invisible' and tried to answer Him, submit to Him, worship Him and express this for the benefit of all human souls that are eternal. She wanted to express this not only by means of the word filled with Christian mystical symbolism ${ }^{4}$, but also by means of the picture - the concrete image of Jesus Christ, the most important element of which is light in the shape of rays coming out of his heart:

${ }^{4}$ The metaphor of fire plays a special role in it, as in The Living Flame of Love by St. John of the Cross. To read more about the mystical language of Saint Faustina, see: Machniak 2000. 
In the evening, when I was in my cell, I saw the Lord Jesus clothed in a white garment. One hand [was] raised in the gesture of blessing, the other was touching the garment at the breast. From beneath the garment, slightly drawn aside at the breast, there were emanating two large rays, one red, the other pale. In silence I kept my gaze fixed on the Lord; my soul was struck with awe, but also with great joy (Kowalska 2005: 35-36).

The rays on the famous painting symbolize the Divine Mercy advocated by Saint Faustina. Although they resemble sunrays and the nun wrote about the 'Divine Sun' and the 'Sun of Divine Grace', they do not burn and do not turn to ash. Just the opposite; in the mystic's oxymoronic imagination, they 'gush' like water from a spring - they moisten, water and give life to people $\mathrm{e}^{5}$. In Skłodowska's monologue, water (if not examinable) means only bodily fluids leaking out of a corpse or ice.

In Radiance can be read like an apocrypha of Skłodowska’s correspondence or like a secret dialogue with Maria Faustyna Kowalska's writings. In the Noble Prize winner's monologue, the Saint appears like Priest Piotr in Konrad's cell, but only in the form of a shadow invisible to the main heroine. Sister Faustina's Diary was written in the years 1934-1938, but its first paragraphs are in the form of a memoir and move us back to the year 1924, when Maria experienced her first vision during a party in a park in Łódź. A few weeks earlier, she had asked her parents to allow her to join a convent, but her request met with their flat refusal. She tried to stifle 'the call of grace' with 'amusements', but in vain. She saw suffering Jesus, ran to the cathedral and there she heard: 'Go at once to Warsaw; you will enter a convent there.' She was eighteen years' old at that time, which was the same as Skłodowska's age in the first monologue of Pałyga's monodrama. Both women's lives are similar thanks to certain biographic motifs (hard and harsh life, diseases, conflicts with the environment) but they attain the level of myth only due to the analogous, though quite different pursuit of goals for which they sacrificed everything. The scientist follows her ingenious intuition concerning the existence of unknown elements with powerful radioactive properties, sacrifices her life for their discovery and separation, and her

5 'O Most Sacred Heart, Fount of Mercy from which gush forth rays of inconceivable graces upon the entire human race, I beg of You light for poor sinners' (Kowalska 2005: 45). 
biggest concern is the correctness of calculations, i.e., the truth of the physical realness of the invisible. The mystic follows the vision of Merciful Jesus, listens to his voice and devotes her life to the transmission of his will, and her biggest concern is certainty, i.e., the truth of the metaphysical realness of God. Skłodowska is afraid of error and she often commits it exposing herself and other people to danger. Eventually, however, their discoveries will be confirmed by experiments of other scientists, and science will follow the direction of research on radioactivity shown by her. 'I turn into radiation. I penetrate, I make an impact' (Pałyga 2016: 70) she will say prophetically in her monologue. Kowalska is afraid of illusion and she often submits to it, sinking into spiritual crises she gets over with the help of her confessors. Eventually, however, she remains certain of her mystical experiences, which the Church will confirm by canonizing Faustina and determining a new path of spiritual development for believers. Moreover, both women are subject to the mysterious transformation process; in the mystic's case, it consists in the personal union with God, and in the scientist's case it is based on the physical (phantasmatic) transformation into cosmic energy, which is understood and perceived as a sort of immortalization: 'Now that I'm already blind and burnt, there is nothing like life, non-life anymore', Maria will say.

When Kowalska experienced her most important revelation in her convent cell on February $22^{\text {nd }} 1931$, Skłodowska-Curie was raising money in America for one gram of radium for Poland. A year later she brought it to Warsaw and both women would have met at that time, had their worlds not been so distant from each other in spite of so many similarities. In May 1932, the Radium Institute was opened, in which Maria's radioactive element was placed. Two years later, in June 1934, Eugeniusz Kazimirowski finished the painting The Image of Merciful Jesus, whose shape had been dictated to him by Sister Faustina (who was dissatisfied with the result of his work, anyway). Skłodowska never saw it. She died of excessive radiation in France on July $4^{\text {th }}$. Meanwhile, The Spirits Book by Hippolyte Rivail was published in Poland...

\section{THE CONSEQUENCES OF INSOMNIA}

Let us make a summary. Skłodowska’s letters written by Pałyga are not necessarily unknown; they rather form a secret, almost esoteric correspondence that is performed like an occult ritual. In Radiance 
triggers the phantasm of alchemical physical and spiritual transformation in imagination. In its centre, there is the Faustian myth, whose dynamic structure binds the most important elements of Maria's soul. The despair after the death of her sister and mother makes Maria rebel against God and want to serve another huge force - deified science symbolized by the Spirit of Earth and Mephistopheles himself. Using the power of will forged in fire, Skłodowska subordinates her whole life to science, and sacrifices herself and the child in return for the received knowledge. She almost literally burns out on the altar of science, but in return she attains a secret - huge radioactivity contained within polonium and radium. Distilled at the cost of Maria's immense physical effort and mental collapse, this second chemical element fulfils the role of the philosopher's stone and is treated by the world as the elixir of life. The Faustian myth triggered in the monodrama spiritualizes the research done by this unusual woman and adds demonic properties to her efforts. Skłodowska calls herself a 'witch'; indeed, her portrait drawn by schoolgirls from the pre-war grammar school could have hung in a museum of former and contemporary heretics, i.e., those who 'have sunk' into books, metal, numbers and the corpse - as Mickiewicz wrote in Konrad's Improvisation - in order to acquire divine wisdom. Maria also 'improvises' by revealing the secrets of her hyperconsciousness and subconsciousness. While Saint Faustina burns out in the fire of divine love, still thirsting for life, the scientist shines with a bright phosphorous flame of knowledge for which she pays with her life. As new Faustina, she becomes a female symbol of Promethean rebellion and a figure of intellectual enlightenment, which has been absent in the Polish imaginarium so far. The brave can make it come alive within them by performing Pałyga's unusual monodrama. Indeed, the consequences of playing with matches at night by one of the most gifted contemporary dramatists are surprising...

\section{Bibliography}

Alan Abyss (2007), Księga magii i zaklęć, transl. R. Roczon, Zielona Góra: Kirke. Das Streben, czyli dążenie. Z Jerzym Jarockim rozmawia Maryla Zielińska (1996), „Literatura na Świecie”, No. 5-6.

Mircea Eliade (1965), Mephistopheles and the Androgyne: Studies in Religious Myth and Symbol, transl. J.M. Cohen, New York: Sheed and Ward. 
Włodzimierz Galewicz (2013), O etyce badań naukowych, [in:] Etyczne i prawne granice badań naukowych, ed. W. Galewicz, Kraków: Universitas.

Johann Wolfgang von Goethe (2003), Faust - Parts 1 \& 2, transl. A.S. Kline, https:// www.poetryintranslation.com/PITBR/German/FaustIScenesItoIII.php.

Barbara Goldsmith (2005), Obsessive Genius: The Inner World of Marie Curie, New

York: W.W. Norton \& Company.

Jak zostać Skłodowską. Z Arturem Pałyga rozmawia Justyna Jaworska (2016), „Dialog”, No. 7-8.

Carl Gustav Jung (1980), Psychology and Alchemy, London: Routledge.

Allan Kardec [Hippolyte Rivail] (1996), The Spirits Book, transl. A. Blackwell,

Brasilia: Federação Espírita Brasileira.

Korespondencja polska Marii Skłodowskiej-Curie 1881-1934 (1994), ed. K. Kabazińska,

M.H. Malewicz, J. Piskurewicz, J. Róziewicz, Warszawa: Instytut Historii

Nauki PAN - Polskie Towarzystwo Chemiczne,.

Maria Faustina Kowalska (2005) Diary of Saint Maria Faustina Kowalska. Divine Mercy in My Soul, Stockbridge: Marian Press,

Jan Machniak (2000), Mistyka świętej Faustyny na tle tradycji chrześcijańskiej

Zachodu, „Peregrinus Cracoviensis”, No. 9.

Adam Mickiewicz (1973), Dziady, part III, Warszawa: PIW.

Friedrich Wilhelm Nietzsche (2006), The Will to Power, transl. A.M. Ludovici, New

York: Barnes \& Noble.

Artur Pałyga (2016), W promieniach. Zupełnie nieznane listy Marii Skłodowskiej-Curie, „Dialog”, No. 7-8.

Albrecht Schöne (1996), Sabat czarownic i kult Szatana w „Fauście” Goethego, transl.

A. Kopacki, „Literatura na Świecie”, No. 5-6.

Małgorzata Szpakowska (2016), Poparzona, „Dialog”, No. 7-8.

Monika Żółkoś (2016), Dramaty kobiecych historii, „Dialog”, No. 7-8.

\section{Summary}

In his essay, author deals with the interpretation of a very original, new monodrama by Artur Pałyga, entitled In Radiance (2016), whose heroine is Maria Skłodowska-Curie. The author is interested in a poetic and performative dimension of Maria's dozen monologues, which the author described as completely unknown letters' of the scientist. These monologues reveal the process of Maria's spiritual development from the moment 
of attaining maturity, until her death due to excessive irradiation. Author focuses on the aspects of Maria's consciousness that Pałyga has brought forth from the myth of Faust, which comprises the foundation of the scientific world-view.

In this monodrama, Skłodowska-Curie is the Polish Faust who is ready to break the moral rules and pay the price of her and others' life for sheer possibility of revealing the mystery of the universe. Kopciński confronts this original literary image of a scientist with the history of her life and highlights the moments in her biography that can be read as the execution of the 'Faustian arrangement'. At the end of his work, he compares the character of Skłodowska-Curie, who calls herself Faustina, with the figure of another extraordinary woman who has also adopted this name - Maria Faustina Kowalska. The comparison of the scientist and the mystic woman allows us to see many similarities in the characters of both, their way of life and their relationships with other people, but it also describes fundamental differences in the world-views they represent. Finally, two Faustinas are two different symbols. The figure of the scientist symbolises desire for the intellectual control of the world, which constantly changes like elements discovered by Maria Skłodowska. On the other hand, the figure of the mysticist symbolises desire for an inner union with loving God, which involves the sacrifice of one's 'self' to gain the eternal life of the immortal soul.

Keywords: In Radiance, Artur Pałyga, monodrama, Maria Skłodowska-Curie, Faust, Faustina Kowalska 